\title{
GUSJIGANG; \\ KARAKTER KEMANDIRIAN \\ MASYARAKAT \\ KUDUS MENGHADAPI INDUSTRIALISASI
}

\section{M.Ihsan}

Ihsan_dr12@yahoo.co.id

\section{Abstrak.}

Data antropologi, demografi dan perilaku ekonomi masyarakat kudus menunjukkan bahwa masyarakat Kudus adalah komunitas yang bercirikan sosial santri-muslim yang bertumpu pada bidang usaha industri pengolahan $(62,72$ $\%$ ) dan perdagangan (24,12\%). Perilaku tersebut dibangun di atas fondasi tradisi lokal Gusjigang. Hubungan antara basis tradisi (local value) dan potensi masyarakatnya (local asset) dengan pelaksanaan industrialisasi seringkali dengan differensiasi structural yang patut dicermati secara serius, terutama ketika hal tersebut berada dalam cengkeraman globalisasi. Intensitas dan cakupan globalisasi ternyata menyentuh hampir seluruh sendi kehidupan. Tidak hanya bidang ekonomi, bisnis, budaya, politik, ideologi, melainkan juga 
telah menjamah ke tataran systems, processes, actors, dan events. Tulisan ini menyajikan data bahwa tradisi Gusjigang mampu dipertahankan dengan baik, sehingga industrialiasasi di Kabupaten Kudus bisa dijadikan model yang relevan sesuai dengan potensi dan karakter masyarakatnya. Selain itu gusjigang sebagai nilainilai kearifan lokal dapat dijadikan sebuah pijakan untuk pengembangan sebuah pembelajaran yang lebih berkarakter. Kebermaknaan pembelajaran dengan lingkup kearifan lokal akan menampilkan sebuah dimensi pembelajaran yang selain memacu keilmuan seseorang, juga sekaligus bisa mendinamisasi keilmuan tersebut menjadi kontekstual dan ramah budaya daerah.

Kata kunci: Gusjigang, tradisi masyarakat Kudus, dan industrialisasi

\section{Abstract}

Anthropological, demographic and economic data of Kudus community indicate that they are social and santri oriented moslem who focus on the business of manufacturing industry $(62.72 \%)$ and trade $(24.12 \%)$. The behavior is built on the foundations of Gusjigang, a local tradition. The relationship between the local value and the local asset with the implementation of industrialization often having structural differentiation should be taken seriously, especially when it is in the grip of globalization. The intensity and scope of globalization has touched almost the whole of life. It has touched not only economics, business, culture, politics, ideology, but also systems, processes, actors, and events. This paper presents data that the Gusjigang tradition is well preserved, so that industrialization in Kudus district can be used as a relevant model in accordance with the potency and character of the community. In addition, gusjigang as the values of local wisdom can be used as a basis 
for the development of more characteristic education. Meaningfulness of education with the scope of local wisdom will display a learning dimension that can not only push a person's knowledge, but also dynamize knowledge into contextual and friendly-culture.

Keywords: Gusjigang, Kudus community tradition, and industrialization 


\section{A. Kerangka Konseptual}

Pembangunan adalah salah satu konsep kunci di era global yang memancing berbagai pertanyaan sulit tentang nilai, teknik dan pilihan. Pembangunan merupakan realisasi potensi manusia yang multidimensi karena mencakup perubahanperubahan penting dalam struktur social dan lembaga kenegaraan. (Coralie dan Louise 1987: 3)

Jika ditelusuri ke belakang, studi tentang pembangunan dapat dirunut hingga pada bidang perhatian filsafat, ekonomi, politik, social dan budaya. Para ahli antropologi mengetengahkan perlunya mengubah sikapsikap tradisional dan menumbuhkan suatu etik/ etos kerja; para ahli politik menekankan perlunya kontrol politik; para ahli administrasi membicarakan

perlunya sistem kepegawaian yang berdasarkan kemampuan; sedangkan para ahli sosiologi mengatakan perlunya model partisipasi dan kepemimpinan.

$$
\text { Namun }
$$

sejak

dasawarsa 1950 hingga 1960, para ekonom cenderung mendominasi perdebatan tentang pembangunan karena merekalah yang paling siap secara konseptual. Mereka mempunyai ukuran yang paling masuk akal, yakni uang.
Karena itu dapatlah dipahami jika kebijakan pembangunan sangat dipengaruhi oleh para ahli ekonomi. Untuk beberapa perencanaan, pembangunan identik dengan pertumbuhan, dan pada gilirannya sinonim dengan industrialisasi yang merupakan proses transformasi structural dari semula mengandalkan sektor primer (pertanian) menuju sektor sektor sekunder (industri) dan kemudian ke sektor jasajasa. Ada dua pendekatan dalam meningkatkan industrialisasi. Yang pertama, dan yang paling sering ditempuh, ialah merangsang sektor industri yang sedang tumbuh. Pendekatan kedua, yang kurang sering ditempuh, ialah memobilisasi sektor tradisional dalam perekonomian untuk melayani tugas industrialisasi. Dasar pemikirannya ialah bahwa rakyat termiskin yang hidup di daerah-daerah pedesaan merupakanangkatan kerja potensial dan sangat diperlukan. Dengan demikian kebijakan ekonomi harus berpusat pada pengendalian dan pemanfaatan sektorsektor tradisional yang belum berkembang demi proses pertumbuhan dan industrialisasi; fokusnya bukan pada impor teknologi Barat. (Rajesh, 1992: 4) Selain itu muncul 
juga istilah produktivitas. istilah ini baru muncul pertama kali pada tahun 1776 dalam suatu makalah yang disusun oleh seorang ekonom Perancis, Francois Quesney, dalam tulisannya yang berjudul Historis Viewpoint of Economic Theories. Sedangkan produktivitas sebagai konsep dengan input dan Output sebagai eleman utamanya pertama kali dicetuskan oleh David Ricardo bersama Adam Smith sekitar tahun $1823 \mathrm{M}$. Ini senada dengan pernyataan Stevenson yang mengatakan bahwa yang disebut produktivitas tak lain adalah indeks untuk mengukur seberapa jauh keluaran relatif dapat di capai dengan mendayagunakan masukan yang dapat dikombinasikan. Penjelasan lebih lanjut tentang produktivitas dikemukakan oleh Adam and Ebert yang menyatakan bahwa productivity can be expressed on a total faktor basis or on partial faktor basis. (W.J. Stevenson, 1993: 36) Inilah yang disebut modernisasi ekonomi". Moore mengidentifikasi proses modernisasi ekonomi menjadi dua, yakni partisipasi pasar dan relokasi sektoral. Partisipasi pasar mencakup gerakan dari pertanian tradisional dan subsisten menuju mekanisasi dan komersialisasi berbagai segmen perekonomian serta peranan aktif dalam dunia pasarrasional.Relokasisektoral mengacu kepada perubahan (pergantian) dari kegiatankegiatan pertanian menjadi non pertanian. Sehingga, pada dasarnya modernisasi ekonomi mengurangi proporsi pertanian dan membuka kesempatan khususnya di bidang manufaktur dan jasa. (M. Francis, 1991: 6)

Diterimanya perspektif ekonomi diatas ternyata menimbulkan dua implikasi yang mendalam. Pertama, pada tahap awal pertumbuhannya, pembangunan membutuhkan investasi besar dari perusahaan nasional dan transnasional untuk kegiatankegiatan produktif. Masalah keadilan dan pemerataan harus ditangguhkan selama beberapa dasawarsa kalau bukannya satu generasi. Kedua, sudah jelas bahwa modernitas tidak selalu mudah atau mulus diterapkan pada kebudayaan tradisional negara-negara sedang berkembangn sehingga budaya, cara berpikir serta preferensi manusia dipandang sebagai hambatan pembangunan. Oleh karena itu persuasi dan otoritas harus dipakai untuk membuahkan pilihan-pilihan. Asumsi tersebut mempunyai implikasi politik yang dimanfaatkan untuk membenarkan kontrol politik, paksaan, dan bahkan 
sering pemerintahan militer.

P e r k e m b a $\mathrm{g}$ a $n$ selanjutnya, pada akhir 1960an dan awal 1970an, para ekonom menyatakan bahwa masalah-masalah ekonomi hanya dapat dipahami dalam konteks realitas politik. Ahli ekonomi politik berangkat dari anggapan bahwa masalahmasalah politik, pemilikan sumber daya, kekuasaan, dan distribusi, berpengaruh besar terhadap proses pembangunan. (Norman dan Warren, 1972: 88)

Di era

gelombang menerjang seantero dunia, sebenarnya globalisasi sendiri bukanlah suatu fenomena baru dalam sejarah peradaban dunia. Sebelum kemunculan nation-state perdagangan dan migrasi lintas benua telah sejak lama berlangsung. Jauh sebelumnya perdagangan regional telah membuat interaksi antar-suku bangsa terjadi secara alamiah. Sejak masa sejarah modern, khususnya sebelum memasuki abad ke-20 ini, globalisasi dipandang sebagai gelombang masa depan. Dua dekade sebelum Perang Dunia I, arus uang internasional telah mengikatkan Eropa lebih erat dengan Amerika Serikat, Asia, Afrika, dan Timur Tengah. Pasar modal mengalami booming di kedua sisi Atlantik, sementara itu bank dan investor-investor swasta sibuk mendiversifikasikan investasinya dari Argentina hingga Singapura. (Collin dan Malcolm, 1997: 1)

Intensitas dan cakupan globalisasi menyentuh hampir seluruh sendi kehidupan. Tidak hanya bidang ekonomi, bisnis, budaya, politik, ideologi, melainkan juga telah menjamah ke tataran systems, processes, actors, dan events, (Jan, 2001: 43) sehingga melahirkan banyak peluang dan tantangan baru. (Walter, 2004: 18-19)

Sekalipun demikian tidak berarti bahwa prosesnya berlangsung dengan mulus. Kecenderungan globalisasi ternyata disertai dengan fragmentasi. Gambarannya akan lebih kentara dengan mengkontraskan elemenelemen dari setiap kecenderungan. Di satu sisi, globalisasi mengandung elemen-elemen: integration, interdependence, multilateralism, openness, dan interpenetration. Di sisi lain, elemen-elemen dari fragmentasi ialah: disintegration, autarchy, unilateralism, closure, dan isolation. Sementara itu, globalisasi mengarah pada globalism, spatial compression, universalism, homogeneity, dan convergency; sebaliknya fragmentasi mengarah pada 
nationalism atau regionalism, spatial distension, separatism, heterogeneity, dan divergency.

Pola fragmentasi ini akan semakin tampak dalam pelaksanaan otonomi daerah. Kebijaksanaan pembangunan ekonomi, bagaimanapun juga, membutuhkan investasi untuk pengembangan usaha berskala besar pada subsektor unggulan tertentu. Usaha-usaha besar dengan kemampuan modal yang tidak terbatas dari perusahaan nasional ataupun internasional pada gilirannya akan memunculkan persaingan (baca: kesenjangan) dengan usaha kecil dan menengah.

$\mathrm{B}$ a $\mathrm{g}$ a i $\mathrm{m}$ a $\mathrm{n}$ a $\mathrm{p} \mathrm{u} \mathrm{n}$ unggulnya kemampuan usaha kecil dan menengah, mereka tetap saja mereka "bukan lawan" pengusaha besar, apalagi perusahaanperusahaan trans-nasional (Multinational Corporation, MNCs). Untuk itulah diperlukan kearifan pemerintah agar keduanya berjalan seiring. Hampir di semua negara maju, seperti Amerika, Jepang, Taiwan, pemihakan pemerintah sangat jelas. Sektor usaha kecil masih merupakan "embrio" yang lemah dan perlu perlakuan khusus.

Keberpihakan inipun pada akhirnya masih menyisakan satu pertanyaan: apakah mereka mampu mendorong munculnya perekonomian daerah? Pertanyaan ini penting karena pemerintah daerah membutuhkan sebuah usaha yang kompetitif dalam harga dankualitas. Kompetensiharga terbentuk dari kemampuan berekspansi sampai pada tingkat produksi yang optimal, yaitu pada tingkat yang menghasilkan biaya rata-rata jangka panjang yang terendah. Sementara itu kompetensi kualitas akan diperoleh dari kemampuan perusahaan untuk selalu memperbarui produknya lewat proses invensi atau inovasi. Hal ini membutuhkan kegiatan riset dan pengembangan (RED) yang melembaga dan built-in dalam proses produksi.

Untuk mengetahui karakter kemandirian masyarakat kudus dalam menghadapi industrialisasi sehingga mampu mendorong perekonomian daerah dengan berbekal kearifan lokal sebagai pijakan filosofisnya, maka tulisan ini berusaha menjawab permasalahan tersebut dengan mengkaji potret pengusahasantri Kudus. Karakter Gusjigang pengusaha Kudus sangat tampak dalam perilaku keseharian mereka. Misalnya, Kartono Ghony, seorang pengusaha emas dan agen elpiji, dulunya adalah pencetak 
batu bata, Djoko Santoso, pengusaha SPBU, yang kini memiliki 4 buah SPBU di Kudus dan Jepara, dan $H$. Sodiqin, seorang pengusaha muda Kudus Kulon, bergerak dalam bidang konveksi dan bordir yang mengutamakan wawasan, jaringan, dan sosok yang religious. Kemudian $\mathrm{H}$. Badrus, seorang pengusaha mebel yang NU, keberagamaan integratif membuatnya tenang, karena setelah berikhtiar semaksimal mungkin, lalu dipasrahkan pada Yang Kuasa. Ini merupakan gambaran yang utuh atas identitas dirinya sebagai individu, serta identitas dirinya sebagai anggota masyarakat yang terikat dengan budaya yang ungul dan telah lama dipegang para pendahulunya.

\section{B. Potret Industrialisasi di Kudus}

Kudus adalah sebuah kota yang secara eksplisit menyatakan dirinya sebagai kota industri berbasis religiusitas. Slogan yang dimunculkan adalah "kota religius-modern". Dengan pilihan di atas, tentu Kudus tidak bisa menghindar dari problem industrialisasi, globalisasi, fregmentasi dan religiusitas (local value) yang berkembang dan mempengaruhi aktivitas perek onomian.

\section{Pilihan}

industri sebagai motor penggerak perekonomian warga Kudus secara ekonomi bisa dimaklumi. Sebab, selama ini sektor tersebut telah menjadi primadona, sebagaimana tampak dalam tabel berikut ini.

Tabel 1

PDRB Berdasarkan Harga Berlaku dan Mata Pencaharian Penduduk Kudus 2016

\begin{tabular}{|c|c|c|c|c|}
\hline LAPANGAN USAHA & PDRB & $\%$ & $\begin{array}{c}\text { JUMLAH } \\
\text { PENDUDUK }\end{array}$ & $\%$ \\
\hline Pertanian & $517.311,99$ & 2,42 & 58.269 & 16,17 \\
\hline Pertambangan \& Penggalian & $7.347,51$ & 0,03 & 1.105 & 0,31 \\
\hline Industri Pengolahan & $13.992 .851,76$ & 65,33 & 150.736 & 41,82 \\
\hline Listrik, Gas \& Air Bersih & $83.444,04$ & 0,39 & 1.477 & 0,41 \\
\hline Bangunan & $270.997,53$ & 1,27 & 34.447 & 9,56 \\
\hline Perdagangan, Hotel \& Restoran & $5.332 .328,07$ & 24,90 & 53.070 & 14,72 \\
\hline Transportasi \& Komunikasi & $323.498,78$ & 1,51 & 17.169 & 4,76 \\
\hline Bank/Lembaga Keuangan lainnya & $419.347,63$ & 1,96 & 4.239 & 1,18 \\
\hline Jasa-jasa & $470.201,23$ & 2,20 & 39.925 & 11,08 \\
\hline TOTAL & $21.417 .328,54$ & 100 & 360.437 & 100 \\
\hline
\end{tabular}

Sumber: Kudus Dalam Angka 2015, Produk Domestik Regional Bruto (PDRB) Kabupaten Kudus Tahun 2015, diolah oleh peneliti 
Berdasarkandatadiatas, Kudus adalah kabupaten yang berbasis pada bidang usaha industri pengolahan $(65.33 \%)$ dan perdagangan $(24,90 \%)$. Maka cukup beralasan kiranya jika dua lapangan itu menjadi gantungan hidup bagi masyarakat Kudus. Penduduk Kudus yang menggantungkan hidupnya kepada sektor industri pengolahan menduduki peringkat pertama (150.736 orang, atau 41.82\%). Kemudian disusul oleh sektor pertanian pada urutan kedua (58.269 orang, atau 16.17), dan sektor perdagangan, hotel dan restoran pada rangking ketiga (53.070 orang, atau $14.72 \%$ ).

Ind us tri-ind ustri tersebut umumnya berada di perkotaan. Maka wajar jika kepadatan penduduk di kota menjadi lebih padat dibanding kecamatan lainnya. Dari Jumlah jumlah penduduk Kudus yang berjumlah 753.529 jiwa, dan jumlah rumah tangganya yang berjumlah
181.169 KK, maka rata-rata jumlah anggota rumah tangga di Kudus adalah 4,15. Tercatat pada tahun 1999 kepadatan penduduk Kudus adalah 1.648 orang $/ \mathrm{Km}^{2}$, pada tahun 2003 kepadatannya adalah 1.705 orang/ $/ \mathrm{Km}^{2}$, dan 1.772 orang/ $\mathrm{Km}^{2}$ pada tahun 2007. Kecamatan terpadat adalah Kecamatan Kota, yaitu 8.773 orang per kilometer persegi dan kecamatan terendah kepadatannya adalah Kecamatan Undaan, yaitu 918 orang per kilometer persegi. Munculnya fenomena industrialisasi di Kudus, di satu sisi memang cukup menggembirakan karena ketersediaan lapangan kerja yang kompetitif. Akan tetapi, di sisi lain, sangat mengkhawatirkan karena industri yang mendominasi ternyata industri berskala besar yang rawan guncangan. Disamping itu, juga muncul problem ketergantungan.

Tabel 2

Profil Industri Kabupaten Kudus Tahun 2015

\begin{tabular}{lccc}
\hline Kecamatan & $\begin{array}{c}\text { Perusahaan/ Unit } \\
\text { Usaha }\end{array}$ & Tenaga Kerja & Nilai Produksi (Juta Rp) \\
\hline 1. Kaliwungu & 1.848 & 13.447 & $6.686 .742,54$ \\
\hline 2. Kota & 2.180 & 138.585 & $31.933 .744,21$ \\
\hline 3. Jati & 1.591 & 28.046 & $31.933 .744,21$ \\
\hline 4. Undaan & 477 & 2.049 & $594.059,72$ \\
\hline 5. Mejobo & 1.822 & 4.652 & $683.807,75$ \\
\hline
\end{tabular}




\begin{tabular}{lccc}
\hline 6. Jekulo & 1.076 & 5.574 & $1.029 .804,66$ \\
\hline 7. Bae & 1.283 & 30.861 & $7.911 .351,64$ \\
\hline 8. Gebog & 1.249 & 20.426 & $3.367 .421,57$ \\
\hline 9. Dawe & 1.412 & 6.399 & $1.645 .268,86$ \\
\hline Jumlah/Total & 12.938 & 250.039 & $133.576 .288,49$
\end{tabular}

sumber : https://kuduskab.bps.go.id data diakses 17 September 2017, diolah peneliti.

Mengingat bahwa Pada sisi lain, secara jumlah perusahaan di Kudus kultural, ada dua karakteristik berjumlah 12.938 unit, ini yang melekat pada masyarakat artinya pemilik perusahaan Kudus. Pertama, Kudus tidak jauh dari jumlah itu. dipersepsikan sebagai sebuah Dengan kata lain, warga komunitas yang lekat dengan Kudus sebagian besar bekerja basis sosial santri-muslim. pada sektor usaha milik orang Dari 724.969 penduduk lain, menjadi buruh. Tercatat Kudus, hampir $98 \%$ memeluk pada tahun 2014, jumlah buruh agama Islam. Kedua, Kudus berjumlah 250.039 orang. dipersepsikan sebagai sebuah kota di Jawa Tengah yang

Tabel 3

Jenis-Jenis Industri Besar dan Sedang di Kabupaten Kudus tahun 2013

\begin{tabular}{clcc}
\hline No & \multicolumn{1}{c}{ Jenis Industri } & Perusahaan & Tenaga Kerja \\
\hline 1 & Makanan \& Minuman & 15 & 1.8 .14 \\
\hline 2 & Pengelolaan Tembakau & 62 & 75.137 \\
\hline 3 & Tekstil & 8 & 1.133 \\
\hline 4 & Pakaian Jadi & 36 & 1.949 \\
\hline 5 & Kulit \& Barang dari Kulit & 11 & 960 \\
\hline 6 & Kayu \& Barang dari Kayu & 8 & 1.304 \\
\hline 7 & Kertas \& Barang dari kertas & 15 & 9.801 \\
\hline 8 & Percetakan & 9 & 2.250 \\
\hline 9 & Industri Kimia \& bahan dari kimia & 5 & 397 \\
\hline 10 & Bahan Galian Bukan Logam & 2 & 57 \\
\hline 11 & Barang dari Logam & 3 & 64 \\
\hline 12 & Elekktronik & 7 & 4.024 \\
\hline & $\quad 181$ & 98.890 \\
\hline
\end{tabular}

Sumber: https://kuduskab.bps.go.id data diakses 17 September 2017, diolahpeneliti. 
memiliki ciri sosial-ekonomi yang khas; rokok, jenang, soto, bordir, dan beberapa produk lainnya. Tidak berhenti disitu saja, masyarakat Kudus terkenal ulung sebagai pedagang antar kota. Mereka telah terbiasa memasarkan barang dagangannya seperti rokok, bordir dan pakaian jadi berhari-hari bahkan berminggu-minggu ke kotakota lain, khususnya ke Jawa Tengah dan Jawa Timur.

\section{Berkaitan}

aktivitas ini,

dengan sering diketemukan perkampungan orang-orang Kudus diluar kota Kudus. Di pusat perbelanjaan di Malang, misalnya, dewasa ini dikenal dengan daerah Kudusan, dan jalan yang melintas di tempat itu disebut Jalan Kudusan. Konon, dahulu daerahitu tempat memusatnya pedagang-pedangang yang berasal dari kota Kudus.

\section{Dalam batas-batas}

tertentu, keuletan dan rajinnya orang-orang Kudus di bidang ekonomi dapat difahami dalam konteks apa yang disebut oleh Benjamin White (1976) sebagai occupational multiplicity. Proses occupational multiplicity adalah semacam proses "ke dalam" untuk menanggulangi kebutuhan ekonomi yang meningkat dengan cara memanfaatkan semaksimal mungkin potensi yang ada untuk berproduksi.
Tidak hanya kaum laki-laki yang harus bertanggung jawab untuk pemenuhan kebutuhan ekonomi, tetapi juga kaum perempuan.

Dua ciri khas Kudus itu, yaitu tradisi santri-muslim yang taat, dan tradisi ekonomi perdagangan dan industri, merupakan fenomena yang menarik dilihat dari antropologi ekonomi, karena adanya unsur sistem nilai yang telah melembaga, hidup, dan mempengaruhi kegiatan ekonomi. Menurut tradisi local, sistem nilai tersebut diyakini merujuk kepada figur Sunan Kudus.

\section{GUSJIGANG: Tradisi Kemandirian sebagai Respon Industri}

Penelitian sumintarsih tentang 'gusjigang etos kerja dan perilaku ekonomi pedagang Kudus' menjelaskan bahwa kata 'gusjigang' mengandung arti 'bagus mengaji - berdagang' adalah filosofi dari Sunan Kudus. Filosofi 'gusjigang' merupakan personifikasi Sunan Kudus agar masyarakat Kudus mempunyai budipekerti yang baik (masalah moralitas, ahklak), pandai mengaji yang berarti menuntut ilmu, rajin beribadah, dan pandai berdagang. Ada yang mengartikan mengaji adalah rajin beribadah, dan 'ji' ada 
yang mengartikan kaji. Jago, terutama jika dilihat dari Ajaran 'gusjigang' ini ada arsitekturdankesamaan ragam yang menyebutkan menonjol hias tumpalnya. Ada pula di wilayah Kudus Kulon yang menyamakan Menara atau wong ngisor menoro. Kudus ini dengan candi di Ada anggapan masyarakat Singosari. Di sebelah halaman, di kawasan ini memiliki terdapat tempat wudlu. tingkat religiusitas dan etos Menariknya, pada lubang kerja lebih tinggi dengan pancurannya ada ornament mereka yang jauh dari Menara Kudus (Kudus bagian timur)

\section{Tradisi}

Gusjigang ditanamkan oleh Sunan Kudus sejak perjumpaannya dengan The Ling Sing, tokoh China mantan nakhoda panglima Cheng Hoo, yang menyepakati lahirnya kota Kudus yang merdeka, tidak terikat dengan kerajaan tertentu dan tidak dimonopoli oleh suku atau agama tertentu.

Ja'far Shadiq dan The Ling Sing mulai memasuki jantung utama sebuah kota. Di Wilayah yang bernama Tajug didirikan sebuah Menara untuk mengumandangkan adzan. Dengan tetap menghormati tradisi Hindu, bangunan Menara dibuat menghadap ke barat dan bentuknya menyerupai bangunan candi yang terbagi atas tiga bagian, yaitu: bagian kaki, tubuh, dan puncak. Para peneliti sepakat bahwa Menara ini jelas bercorak mirip bangunan candi atau menara kul-kul Bali. Beberapa peneliti menghubungkan bentuk Menara itu dengan candi berbentuk kepala arca yang berjumlah delapan. Delapan pancoran ini mengandung filosofi Astasanghikanarga dalam agama Budha, yakni pengetahuan, keputusan, perkataan, perbuatan, penghidupan, daya usaha, meditasi dan kontemplasi.

$$
\text { Sampai di sini }
$$

lengkaplah sudah fondasi sebuah kota. Idealitas sebuah wilayah yang multi etnik multi religi sudah berdiri. Masalahnya tinggal penamaan. Sebagai sebuah pesan perdamaian dunia, di mana pusaran konflik saat itu berada di Yerussalem, maka Sayyid Ja'far Shadiq menamai masjidnya dengan "Masjid alAqsha", kota yang damai itu diberi nama al-Quds (Kudus), dan Gunung yang menjulang tinggi di sebelah utara diberi nama Muria. Kota ini dibangun atas dasar kebersamaan, multi etnis (Arab-China-Jawa), multi religi (Islam-Hindu-Budha) dan bertumpu pada sektor perdagangan dan industri.

Untuk memulailangkah besar itu, wilayah Loram 
menjadi pilihan. Wilayah ini dipilih karena subur dan dekat dengan jalur transportasi. The Ling Sing yang memiliki keahlian mengukir (sungging) menularkan ilmunya kepada warga lokal. Hingga kini, jejak ukiran dan semangat bisnisnya masih nampak. Sementara Sayyid Ja'far Shadiq yang berlatar belakang militer dan ahli agama mencoba merangkul masyarakat untuk bersatu, ber-tepaselira dan menghargai perbedaan suku, agama dan ras. Semua pihak mesti merevolusi perilaku, meningkatkan spiritualitas dan menata basis ekonominya. Semangat ini secara tutur tinular dikenal masyarakat dengan istilah GUSJIGANG (Bagus, Kaji, Dagang).

Filisofi 'gusjigang' memiliki arti penting dalam kehidupan masyarakat Kudus. Bagaimana ajaran 'gusjigang' ini dipahami dan merasuk dalam perilaku pedagang Kudus, sangat dipengaruhi oleh pemaknaan orang Kudus terhadap filosofi 'gusjigang' itu sendiri. Dalam konteks ini makna mengacu pada pola-pola interpretasi dan perspektif yang dimiliki bersama yang terekspresi dalam simbol-simbol.

Dalam telaah makna 'gusjigang' dalam kehidupan orang Kudus, dengan memperhatikan pandangan 'dari dalam', yaitu dari sudut pandang tineliti (orang Kuduspedagang) yaitu world view orang Kudus atas etos dalam 'gusjigang'. Dalam kerangka ini pemaknaan 'gus- ji gang' pada pedagang Kudus mengandung tiga unsur nilai yang berbeda. Pengungkapan makna'gus' (bagus ahklaknya) akan berbeda analisisnya dengan pengungkapan makna 'ji' (belajar, menuntut ilmu), dengan pemaknaan 'gang' (pandai berdagang). Namun ketiga unsur ini adalah satu kesatuan. Artinya, seseorang (pedagang) yang menjalankan 'ji' dan 'gang' sebagai pedagang yang menjalankan praktik berdagang dengan baik, maka dalam konteks ini seseorang pedagang tersebut dapat disebut memiliki 'gus'

Mengacu pernyataan Tjokroaminoto bahwa etos kerja berbeda antar berbagai segmen masyarakat, maka perilaku ekonomi pedagang dalam bingkai 'gusjigang' ini juga akan difokuskan pada pedagang yang berdagang cukup menonjol di Kudus seperti usaha konveksi, usaha kain bordir, usaha jenang kudus. Pedagang tersebut dengan klasifikasi pengusaha pemilik usaha (konveksi, bordir, jenang), pedagang penjual eceran maupun borongan (konveksi, bordir, jenang), pedagang pengusaha 
maupun eceran etnik Cina, Arab, dan Jawa.

Untuk bisa disebut sebagai wong Kudus, seseorang harus memiliki perilaku 'gus', bagus rupa dan bagus laku. Begitu seseorang buruk lakunya, tentu akan berakibat panjang, paling tidak akan mengurangi kepercayaan orang lain terhadap dirinya, dan pada gilirannya akan merugikan usaha dagangnya.

Orang yang bagus perilakunya disebut saleh. Kesalehan seseorang disimbolisasikan dengan kaji. Mengapa kaji? Karena haji adalah simbol spiritualitas seseorang yang sudah melewati berbagai tahapan sebelumnya, seperti syahadat, shalat, puasa dan zakat. Dan tentu saja secara ekonomi seorang kaji sudah masuk kategori mampu, karena ongkos naik haji terbilang tidak murah, sehingga status kaji identik dengan identitas pengusaha.

Sementara dagang merupakan karakter khas yang hendak dibangun oleh Sayyid Ja'far Shadiq. Bisnis perdagangan yang hendak ditradisikan oleh Sayyid Ja'far Shadiq adalah perdagangan yang jujur: jika berbicara tidak bohong, jika berjanji tidak mengingkari, jika dipercaya tidak berkhianat, jika membeli tidak mencela, jika menjual tidak memuji, jika berhutang tidak lalai, dan jika punya piutang tidak mempersulit. Jadi, perilaku gusjigang secara umum dicirikan oleh unsur-unsur kewirausahaan. Umumnya mereka memiliki kejelian membaca peluang, kreatif, dan senantiasa menundukkan rasa takut sehingga mampu bertahan dalam oposisi sosial.

H. Kartono Ghony, seorang pengusaha emas dan agen elpiji, dulunya adalah pencetak batu bata, kemudian menjadi pedagang pakaian keliling (Jawa: mindring), hingga akhirnya seperti sekarang. Dia bertutur:

"Saya menjadi pengusaha ya karena terpaksa, mas. Saya tiga bersaudara, bapak sudah meninggal, dan ibu saya pengangguran. Untuk bertahan hidup saya dan saudara saya (yang satu perempuan) nyithak boto. Karena dirasa terlalu berat, maka uang hasil bata saya belikan pakaian dan saya edarkan di pabrik-pabrik rokok. Pengalaman pedagang keliling ini kemudian membawa saya menjadi mindring emas, hingga akhirnya memiliki toko emas. Jadi kalau ditanya spirit apa, ya 
ingin bertahan hidup" (wawancara Pribadi, 22 Agustus 2011)

Halsenada disampaikan oleh Djoko Santoso, pengusaha SPBU, yang kini memiliki 4 buah SPBU di Kudus dan Jepara. Dalam wawancara dengan peneliti dia mengatakan bahwa motif utama dia jadi penguasa dulu adalah ingin bertahan karena dia perantauan dari Solo. Karirnya dimulai dari menjadi operartor, kasir, manajer, sampai memiliki SPBU sendiri. (Wawancara Pribadi, 4 Oktober 2011)

Hal yang kurang lebih sama dialami oleh Thomas Budi Santoso, seorang Tiong Hoa dari Pati yang kini menjadi Direktur Produksi PT Djarum. Dia dilahirkan dari keluarga miskin, rumahnya di tanah milik PJKA, dan untuk sekolah dia menjual air keliling. Lulus SLTA dia menjadi agen keliling rokok, kumudian menjadi kepala brak, hingga kini menjadi direktur produksi pabrik rokok terbesar di Indonesia. (Wawancara Pribadi, 23 Juli 2010)

Bagi pengusaha dengan latar belakang confidence modalities, di mana orang tersebut lahir dan atau dibesarkan dalam keluarga yang memiliki tradisi yang kuat di bidang usaha, dan emotion modalities, di mana seseorang memang mempersiapkan diri untuk menjadi wirausahawan, spirit yang menggerakkan mereka adalah prestasi.

Sebagai individu, para penguasaha tersebut adalah manusia biasa yang terdiri dari sekumpulan organisme yang hidup dan bersenyawa. Oleh karena itu pola perilakunya menampakkan ciri behavioristik yang berlaku hukum SOR (StimulusOrganisme-Respon). Oleh karena wong Kudus juga hidup dalam lingkungan sosial, maka objek yang direspon tersebut sebenarnya berdialog dan saling mengisi dengan stimulan-stimulan yang menggugah. Stimulan ini akhirnya berdampak pada meningkatnya proses terjadinya perilaku. Proses ini dapat diformulasikan dengan $B$ $=\mathrm{f}(\mathrm{E}, \mathrm{O})$ atau Behavior, fungsi, Environment, (Albert, 1977: 71)

Organisme.

Sebagai sebuah gejala psikis, proses lahirnya perilaku gusjigang tidak lahir dengan serta merta, melainkan setelah melalui proses psikis berupa: Awareness (kesadaran) dimana orang tersebut menyadari dalam arti mengetahui terlebih dahulu terhadap stimulus (objek); Interest (merasa tertarik) dimana orang mulai tertarik terhadap stimulus; 
Evaluation (menimbangnimbang) terhadap baik dan tidaknya stimulus tersebut bagi dirinya; Trial dimana subjek mulai mencoba melakukan sesuatu dengan apa yang dikehendaki oleh stimulus, dan; Adoption dimana subjek telah berperilaku baru sesuai dengan pengetahuan kesadaran terhadap stimulus. (Notoatmodjo, 2003: 56)

Nilai-nilai seperti ini, setelah melalui proses waktu yang cukup, melembaga dan yang pada akhirnya terlembagakan dalam tata nilai masyarakat Kudus, bersifat evaluatif, dan sekaligus merupakan bagian dari tradisi atau budaya masyarakat secara keseluruhan. Hal ini karena secara psikis seseorang cenderung memasukkan segala sesuatu yang berasal dari luar dirinya seperti simbol-simbol yang mencerminkan dunia di sekitarnya, norma, budaya, kehidupan sosial, serta perilaku orang yang akrab dengannya ke dalam sistem gejala kejiwaannya. Proses internalisasi pengalaman ini kemudian mempengaruhinya dengan cara tertentu ketika memahami, merasa, berpikir dan berbuat. (Vinacke, 1992: 285)

Perilaku Gusjigang bagi masyarakat Kudus merupakan fenomena yang sulit dibantah. Setidak-tidaknya sejak zaman penjajahan, mereka telah terkenal dengan perilaku tersebut, dan ini tentu saja berbeda jauh dengan perilaku ekonomi yang bersifat subsisten. Perilaku tersebut menarik bagi penguasa kolonial. Mereka sempat mempersoalkan pula mengapa masyarakat Kudus mempunyai perilaku ekonomi yang berbeda dari perilaku ekonomi masyarakat Indonesia pada umumnya. Bagi penguasa kolonial, masyarakat pribumi dilukiskan sebagai masyarakat yang miskin dan pemalas.

Di bidang perdagangan, masyarakat Kudus terkenal ulung sebagai pedagang antar kota. Mereka telah terbiasa memasarkan barangbarang dagangannya, seperti bordir, pakaian, batik, yang berkembang berhari-hari bahkan berminggu-minggu ke kota-kota lain, khususnya ke Jawa Tengah dan Jawa Timur. Berkaitan dengan aktivitas ini, sering diketemukan perkampungan orang-orang Kudus di luar kota Kudus. Di pusat perbelanjaan di Malang, misalnya, dewasa ini dikenal dengan daerah Kudusan, dan jalan yang melintas di tempat itu disebut Jalan Kudusan. Konon, dahulu daerah itu tempat memusatnya pedagang-pedangang yang berasal dari kota Kudus. Menurut laporan 
A.D.A. de Kat Angelino, pejabat urusan Cina di Jakarta (Batavia) melukiskan bahwa keuletan, kerajinan, dan perilaku hemat yang ditunjukkan oleh masyarakat Kudus disebabkan oleh adanya percampuran darah Cina pada mereka. (YM3SK dan CERMIN, 2001) Benar tidaknya kesimpulan De Kat Angelino memang masih perlu diperdebatkan. Akan tetapi yang jelas masalah keuletan, kerajinan, dan perilaku hemat masyarakat Kudus telah dikenal oleh masyarakat luas, tidak saja pada tingkat lokal, tetapi bahkan sampai pada tingkat pusat.

Dalam

batas-batas tertentu, keuletan dan rajinnya orang-orang Kudus di bidang ekonomi dapat difahami dalam konteks apa yang disebut oleh Benjamin White (1976) sebagai occupational multiplicity. Diilhami oleh teori involusi Geertz (1963), White mempertanyakan apa yang terjadi pada masyarakat yang mata pencaharian utamanya pada sektor industri, atau usaha kecil apabila mereka dihadapkan pada fenomena peningkatan jumlah penduduk yang cepat dan kebutuhan ekonomi yang meningkat.

Proses occupational multiplicity adalah semacam proses "ke dalam", sebagaimana proses involusi yang terjadi pada masyarakat petani, untuk menanggulangi kebutuhan ekonomi yang meningkat dengan cara memanfaatkan semaksimal mungkin potensi yang ada untuk berproduksi. Tidak hanya kaum laki-laki yang harus bertanggung jawab untuk pemenuhan kebutuhan ekonomi, tetapi juga kaum wanitanya. Fenomena ini memang bukanlah fenomena yang berlaku, atau yang terjadi hanya pada masyarakat Kudus saja, akan tetapi keterlibatan seluruh anggota keluarga dalam menjalankan usaha yang dikembangkan dalam masyarakat Kudus sangatlah dominan. Istri pedagang kain bordir misalnya, mempunyai keahlian membordir dan pembordir yang handal. Sistem borongan dalam pembuatan bungkus rokok kretek merupakan cara yang telah mentradisi di kalangan wanita penduduk Kudus. Peran tersebut dilakukan bersamaan dengan peran mereka yang lain. Demikian juga pengusaha atau pekerja laki-laki, mereka sering mempunyai peran ganda dalam berusaha. Ini semua menggambarkan tingkat keuletan dan kerajinan mereka dalam menghadapi industrialisasi (YM3SK dan CERMIN, 2001) 


\section{GUSJIGANG: Kearifan Lokal sebagai Pijakan Pendidikan Karakter}

Kearifan

lokal

merupakan produk budaya masa lalu yang patut secara terus-menerus dijadikan pegangan hidup. Meskipun bernilai lokal tetapi nilai yang terkandung di dalamnya dianggap sangat universal. Sehingga dengan mengintegrasikan kearifan lokal dalam desain pembentukan karakter anak, secara tidak langsung anak akan mendapatkan gambaran yang utuh atas identitas dirinya sebagai individu, serta identitas dirinya sebagai anggota masyarakat yang terikat dengan budaya yang ungul dan telah lama dipegang para pendahulunya.

Karakter Gusjigang pengusaha Kudus sangat tampak dalam perilaku keseharian mereka. $\mathrm{H}$. Sodiqin, misalnya, seorang pengusaha muda Kudus Kulon yang bergerak dalam bidang konveksi dan bordir bercerita tentang perilaku keberagamaannya:

"Saya mengawali usaha sebagai seorang buruh, aktif di kampung sebagai bendahara masjid. Sebagai pengusaha, saya mengutamakan wawasan, jaringan, dan tidak fanatik pada politik dan ormas tertentu. Saya juga harus supel dan ramah kepada semua orang, Jika di dzalimi orang, misalkan hutang tidak bayar, saya percaya bahwa Allah pasti akan mengganti dengan rizki yang lain. Shalat 5 waktu juga tidak pernah saya tinggalkan, bahkan harus dengan berjama'ah. Setiap minggu, saya membaca shalawat nariyah 4444 kali" (W a w a n c a r a Pribadi, 17 November 2011)

$\begin{array}{cr}\text { Sebagai } & \text { sebuah } \\ \text { respon, tidak semua }\end{array}$ perilaku mampu melahirkan karakter gusjigang karena ia merupakan pengalaman yang memungkinkan individu naik pada tingkat kesadaran, sehingga mampu merepresentasikan potensi melebihi aktualisasi diri. Tingkat ini tidak bisa dicapai dengankeberagamaansimbolis yang hanya mengutamakan sisi form norma dan dogma belaka. Sebab, sebuah perilaku keberagamaan pasti terdiri atas sejumlah satuan perbuatan. Setiap butir satuan keberagamaan berpeluang memiliki sejenis hubungan antara satu dengan lainnya, sesuai dengan peringkat dan karakter dalam struktur internal masing-masing. 
Himpunan

ini pada akhirnya akan membentuk suatu struktur satuan keberagamaannya sendiri, yang sering disebut sebagai tipe keberagamaan.( Muslim A. Kadir, 2011: 102)

Apa yang ditampakkan pengusaha Kudus berbeda dengan model-model religiusitas simbolik pada umumnya. Religiusitas mereka menampakkan ciri integratif karena meramu beberapa komponen yang mengitari religiusitas itu sendiri. Religiusitas mereka dipadupadankan dengan keterlibatan ritual (ritual involvement), keterlibatan Teologis (theological involvement), keterlibatan intelektual (intellectual involvement) dan keterlibatan pengalaman (experiential involvement).

H. Badrus, seorang pengusaha mebel yang NU, menyatakan bahwa keberagamaan integratif membuat dia tenang karena setelah ia berikhtiar semaksimal mungkin, lalu ia pasrahkan pada Yang Kuasa. "Dengan cara ini saya tentram. Kabeh wis tinakdir sangking Pengeran" katanya. (Wawancara Pribadi, 17 November 2011)

Yang perlu dicatat adalah bahwa Intelektualitas seseorang juga mempengaruhi kadar keberagamaannya. Secara fitrah manusia memiliki dasar-dasar keilmuan yang bersifat teologis-metafisik, sebab manusia diciptakan berdasarkan fitrah, yaitu membawa potensi beragama yang lurus, dan fitrah ini merupakan bagian dari penciptaan Allah. ( Quraish Shihab, 1996:283)

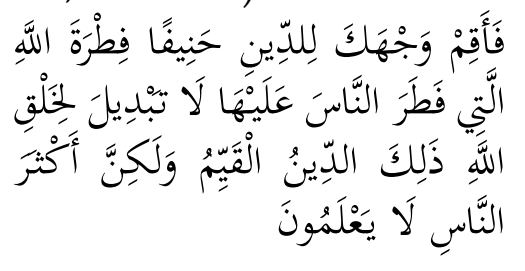

"Maka hadapkanlah wajahmu dengan lurus kepada agama (Allah); (tetaplah atas) fitrah Allah yang telah menciptakan manusia menurut fitrah itu. Tidak ada perubahan pada fitrah Allah. (Itulah) agama yang lurus; ${ }^{\{1\}}$ tetapi kebanyakan manusia tidak mengetahui" (QS. al$R u>m: 30)$

Berdasarkan ayat-ayat diatas, baik unsurfisik ataupun metafisik dapat "dicapai" secara relatif oleh manusia jika dalam melakukan kajian dan penelaahan terhadap obyek-obyek tersebut manusia menggunakan pendekatan dan metodologi yang tepat sesuai dengan obyek kajiannya. Islam menandaskan bahwa sumber dari seluruh ilmu pengetahuan 
manusia tersebut berasal dari sang Pencipta sendiri.

Produk

dari

keberagamaan integratif ini akan mengantarkan manusia pada jati dirinya yang kokoh. Secara vertikal akan mengantarnya pada kepada Allah, dan secara horizontal akan menghasilkan ketaqwaan; suatu sikap dan tindakan untuk melabuhkan diri secara tepat dalam tensi moral, hingga pada gilirannya akan menumbuhkan pertanggungjaw a ba n terhadap segala apa yang telah dilakukannya.

Inilah fitrah manusia, mengembalikan intelektualitas kepada spiritualitas sebagai bagian dari penciptaan dan bahkan menjadi tujuan akhirnya, sebagaimana firman Allah di surat al-Dhariyat:

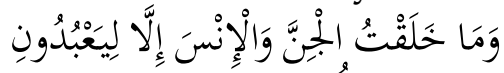

إنما

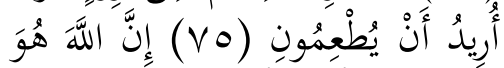

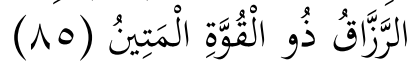

"Dan Aku tidak menciptakan jin dan manusiamelainkansupaya mereka menyembah-Ku. Aku tidak menghendaki rezeki sedikit pun dari mereka dan Aku tidak menghendaki supaya mereka memberi Aku makan. Sesungguhnya Allah Dialah Maha
Pemberi rezeki Yang Mempunyai Kekuatan lagi Sangat Kokoh." (QS. al-Dha>riya>t 51: 56-58)

Menarik

untuk dicermati, mengapa Allah mengaitkan ketulusan hamba untuk menyembah dengan hadirnya rizki dan makanan? Al-Qurtubi menjelaskan bahwa siapa yang menyembah Allah dengan tulus, bukan saja ia telah melakukan kewajibannya, tapi ia akan mendapatkan rizki. Dikisahkan, bahwa ketika Nabi Muhammad merasa ada kesulitan (rizki), maka Nabi memerintahkan keluarganya untuk shalat, kemudian membaca ayat ini. Hal yang sama juga dilakukan oleh Umar ibn Khattab. (AlQurtubi, tt: 263)

Tradisi inilah yang ditanamkan melalui pendidikn karakter pada masyarakat Kudus. Tradisi GUSJIGANG tidak lagi diperlakukan sebagai pepatah suci yang hanya dihafalkan belaka, tapi benar-benar dipraktekkan dalam perilaku kongkrit. Gusjigang juga tidak dipahami sebagai sebuah norma saja, akan tetapi mesti diperlakukan sebagai sebuah "organisme" yang hidup, berkembang, dan mempengaruhi orang yang dihinggapi. Nilai-nilai tersebut tidak lagi diperlakukan 
sebagai pepatah suci yang hanya dihafalkan belaka, tapi benar-benar dipraktekkan dalam perilaku kongkrit sebagai bentuk religiusitas mereka. (Muslim, 2003: 227)

Dengan sinergitas komponen-komponen di atas, maka karakter gusjigang akan menghasilkan sosok yang mampu ber-relasi secara intrapersonal (hubungan antara diri sendiri), interpersonal (hubungan antara orang lain dengan lingkungan) dan transpersonal (hubungan dengan kekuatan tertinggi), sehingga layak disebut cerdas dan berkarakter.

Karakter, secara etimologis berasal dari bahasa Yunani "karasso", berarti "cetak biru", "format dasar", "sidik" seperti dalam sidik jari. Sedangkan menurut istilah, ada beberapa pengertian mengenai karakter itu sendiri. Secara harfiah Hornby dan Parnwell mengemukakan karakter artinya "kualitas mental atau moral, kekuatan moral, nama atau reputasi" . (Muslim, 2003: 49)

Dalam Islam, kata yang paling dekat untuk menunjukkan karakter adalah akhlak. Al-khulq (bentuk mufrad/tunggal dari kata akhlaq) berarti perangai, kelakuan, dan gambaran batin seseorang. Pada dasarnya manusia itu mempunyai dua gambaran, yakni gambaran lahir dan gambaran batin. Gambaran lahir berbentuk tubuh yang nampak secara fisiologis, sementara gambaran batin adalah suatu keadaan dalam jiwa yang mampu melahirkan perbuatan, baik yang terpuji maupun tercela. (Muhammad bin Shalih, 2001:12)

$\begin{array}{cr}\text { Eksistensi } & \text { akhlak, } \\ \text { dalam perspektif ilmu }\end{array}$ pengetahuan modern, terhubung dengan 'modul Tuhan' atau 'God Spot'. Dikatakan bahwa dalam struktur batin manusia ada jaringan syaraf yang berkaitan dengan pengalaman religi atau spiritual. Michael Persinger (Cambridge University) dan Ramachandran (California University) menyebutnya sebagai "God-spot" (titik Tuhan/modul Tuhan). Modul ini bersifat built in, semenjak pre-existence, atau sejak nur cahya putih wujud ingsun, atau sejak masih dialam dzar. Dalam istilah al-Ghazali, akhlak berkoneksi dengan nafs yang kemudian berintraksi dengan ruh, 'aql dan qalb.

Dalam konteks yang lebih luas, pendidikan berbasis kearifan lokal dapat digunakan sebagai media untuk melestarikan budaya. Hal penting dalam konteks pendidikan adalah adanya kebijakan pemerintah tentang 
adanya otonomi pendidikan dan otonomi daerah. Dilihat dari sisi visi utama otonomi penyelenggaraan pendidikan sebagai upaya pemberdayaan masyarakat madrasah (school community) untuk menentukan sendiri jenis dan muatan kurikulum, proses pembelajaran dan sistem penilaian hasil belajar, guru, kepala sekolah, fasilitas dan sarana belajar. Fenomena yang demikian diharapkan menjadi kekuatan daerah dalam rangka mewujudkan otonomi, baik melalui restrukturisasi maupun deregulasi untuk menjamin otonomi pendidikan berjalan sebagaimana mestinya, dalam arti bahwa masyarakat terberdayakan

untuk mengelola dan mendapat pelayanan pendidikan secara adil dan merata, yang semuanya itu dijamin oleh peraturan perundangan.

Kearifan lokal harus dikembangkan dari potensi daerah. Potensi daerah merupakan potensi sumber daya spesifik yang dimiliki suatu daerah tertentu. Dalam pendidikan karakter berbasis kearifan lokal, pedoman nilai-nilai kearifan lokal merupakan kriteria yang menentukan kualitas tindakan anak. Sebagai sebuah kriteria yang menentukan, nilai-nilai kearifan lokal bisa menjadi sebuah pijakan untuk pengembangan sebuah pembelajaran yang lebih berkarakter. Kebermaknaan pembelajaran dengan lingkup kearifan lokal akan menampilkan sebuah dimensi pembelajaran yang selain memacu keilmuan seseorang, juga sekaligus bisa mendinamisasi keilmuan tersebut menjadi kontekstual dan ramah budaya daerah.

Pendidikan

dipelopori

yang

Walisongo menurut Rahman, merupakan perjuangan brilliant yang diimplementasikan dengan cara sederhana, yaitu menunjukkan jalan dan alternatif baru yang tidak mengusik tradisi dan karena pendekatan-pendekatan Walisongo yang konkrit realistis, sederhana dan menyatu dengan kehidupan masyarakat. Dan yang lebih penting adalah teknik peran langsung oleh para wali. Usaha-usaha ini dalam konsep modern sering diterjemahkan sebagai "model of development from within". Model ini sekali lagi menunjukkan keunikan Sufi Jawa yang mampu menyerap elemen-elemen budaya lokal dan asing tapi dalam waktu yang sama masih berdiri tegar di atas prinsipprinsip Islam. (Abdurrahman, 1997: 76) Kemenangan dalam kedamaian ini oleh para 
sejarawan sering disebut sebagai "zaman kuwalen". (Mark, 1999: 116)

Dengan akar sejarah Kangjeng Sunan Kudus; Syaih Ja'far Shodiq memiliki basis ekonomi dan ilmu yang sangat kuat. Sehingga dalam konteks Kudus, Kangjeng Sunan Kudus didudukkan sebagai pendiri kota. Beliau hadir di tengah masyarakat tidak hanya sebagai pendiri kota, akan tetapi yang jauh lebih penting adalah sebagai pendidik masyarakat, sebagai wujud dari perilaku pewaris nabi. Sampai saat ini ketokohan Sunan Kudus apat dilihat dan dirasakan dalam sebagian besar masyarakat Kudus. Kehadiran Sunan Kudus dalam ruang spiritual terbukti sampai saat ini dengan lestarinya atributatribut atau symbol yang selalu diasosiasikan dengannya.

Gusjigang merupakan falsafah hidup yang diajarkan oleh Sunan Kudus yang jika dijabarkan terdiri dari 3 rangkaian kata yaitu 'gus' bagus, 'ji' mengaji, 'gang' berdagang. Falsafah ini memang sederhana tetapi telah membangun masyarakat Kudus dari berbagai aspek, terutama adalah aspek religi, ekonomi, dan sosial budaya. Gusjigang itu sebenarnya tidak hanya berupa falsafah hidup tetapi juga sebagai suatu kebudayaan dan juga sebagai sebuah pendidikan karakter yang telah lama diterapkan kepada masyarakat Kudus.

Gus atau Bagus sebagai soft skill merupakan singkatan dari bagus yang berarti bagus akhlak budi pekertinya. Masyarakat Kudus, khususnya pengikut atau santri santri dari Sunan Kudus diajarkan bagaimana menjadi manusia yang berakhlak mulia agar selamat dunia akhirat. Pengajaran dan penyebaran pembangunan karakter di masyarakat Kudus memang berlangsung agak lama karena masyarakat Kudus pada awalnya mayoritas beragama Hindu dengan kepercayaan yang kental yang berupa animisme dan dinamisme.

Seseorang yang dekat dengan Allah adalah seseorang yang harus mempunyai akhlak yang bagus. Oleh karena itu Sunan Kudus mengajarkan bagaimana menjadi manusia yang berbudi luhur dan berakhlak mulia, karena jika seseorang berakhlak jelek maka manusia tersebut semakin menjauh dengan Allah.

Penerapan akhlak sopan, santun dan etika pada generasi muda dapat digunakanuntukmembentengi diri dari pengaruh negatif modernisasi dan globalisasi yang jika tidak di bentengi 
akan memporakporandakan kehidupan masyarakat di segala bidang. Penerapan akhlak yang lebih ditekankan pada generasi muda karena generasi muda akan menjadi penerus bangsa yang memiliki akhlak mulia akan memajukan bangsa dan negara di masa mendatang. Jadi penerapan ini diharapkan dapat menciptakan masyarakat Kudus yang religius sesuai dengan sebutan Kota Kudus sebagai Kota Santri.

Ji atau pintar mengaji sebagai hard skill disini merupakan singkatan dari mengaji yang berarti belajar. Belajar yang diajarkan Sunan Kudus. Mengaji, khususnya mengkaji kitab Islami untuk mengetahui bagaimana hubungan dengan Allah agar dapat mendekatkan diri kepada Allah. Hal ini masih berada pada masyarakat Kudus sampai saat ini dengan bukti yaitu sebagian besar generasi muda yang berada di Kudus menuntut ilmu baik itu melewati lembaga formal maupun non formal, bahkan pelajar-pelajar dari luar kudus berbondong-bondong untuk menimba ilmu di kota ini.

Di samping itu mengaji di sini bukan hanya sekedar belajar kitab-kitabIslami, tetapi juga belajar berkehidupan dan bersosialiasi dengan sesama umat manusia. Dengan adanya mengaji yang diterapkan kepada masyarakat Kudus, maka akan menjadi pribadi yang cerdas.

Gang "berdagang". Berdagang merupakan salah satu ajaran yang diajarkan oleh Sunan Kudus kepada para pengikutnya untuk dapat bertahan hidup. Sebenarnya bertahan hidup tidak hanya dapat dilakukan dengan cara berdagang tetapi juga dapat dilakukan dengan cara apa saja misalnya dengan bercocok tanam, berternak, dan lain-lain. Sosok Sunan Kudus dikenal sebagai saudagar / pengusaha ulet untuk mendukung misi dakwahnya menjadi pelopor dan teladan bagi masyarakat Kudus terutama di sekitar Kudus Kulon. Sunan Kudus mengajarkan cara bagaimana bertahan hidup dengan berdagang yang pada saat itu Sunan Kudus adalah seorang pendatang baru yang datang ke Kudus untuk menyebarkan agama Islam kepada masyarakat Kudus. Beliau datang tidak hanya untuk menyebarkan agama Islam tetapi juga membangun karakter Berdagang tidak hanya sekedar untuk bertahan hidup dan mencukupi kebutuhan duniawi, tetapi juga dapat diniatkan untuk ibadah kepada Allah SWT, sekaligus untuk mendukung dakwah pada saat itu. Dalam 
berdagang setiap orang dapat bertemu dengan orang lain dengan beragam latar belakang. Hal tersebut dapat dijadikan peluang untuk menyebarluaskan dakwah Islam. Oleh karena itu, salah satu Implementasi dari falsafah gusjigang tersebut adalah meningkatkan kepedulian dan semangat menyebarluaskan dakwah Islam dengan dukungan yang kuat dari usaha dagang atau bisnis seperti yang dilakukan Sunan Kudus pada masanya. Tidak hanya berdagang untuk mencari keuntungan saja, tetapi juga untuk dukungan dakwah Islam.

Falsafah Gusjigang yang diajarkan Sunan Kudus dalam membangun karakter masyarakat Kudus menjadi lebih baik merupakan salah satu aplikasi pemanfaatan nilai-nilai kearifan lokal sebagai basis pendidikan karakter. Guru, sebagai kunci dalam proses pembelajaran dan pendidikan diharapkan memiliki profil yang sesuai dengan karakter masyarakat dan sesuai dengan tuntutan perkembangan. Dalam proses pembelajaran harus memulai memunculkan dan menginternalisasikan nilainilai kearifan lokal tersebut, sebagai pijakan dan spirit dalam setiap mendidik siswanya. Sehingga dari pola yang demikian, guru akan menjadi seorang fasilitator yang baik bagi internalisasi nilai-nilai kearifan lokal pada diri peserta didik yang bersinggungan langsung dalam proses pembelajaran.

Pada posisi ini, nilai yang terkandung dalam bingkai kearifan lokal sebuah daerah akan menjadi senjata yang ampuh untuk membangun karakter anak bangsa, agar memiliki jiwa nasionalisme yang tinggi sekaligus mampu menjadi penjaga kelestarian kearifan lokal tersebut melalui sikap keseharian yang berkarakter kuat.

Dengan pendidikan yang berbasis pada local wisdom (kearifan lokal) maka kita bisa optimis akan terciptanya pendidikan yang mampu memberi makna bagi kehidupan manusia Indonesia. Artinya pendidikan kemudian akan mampu menjadi spirit yang bisa mewarnai dinamika manusia Indonesia kedepan. Pendidikan nasional kita harus mampu membentuk manusia yang berintegritas tinggi dan berkarakter sehingga mampu melahirkan anakanak bangsa yang hebat dan bermartabat sesuai dengan spirit pendidikan yaitu memanusiakan manusia. 


\section{E. Kesimpulan}

Tradisilokalmasyarakat Kudus yang merujuk kembali kepada figur Sunan Kudus merupakan modal dasar dalam berkehidupan. Hal ini tercermin dalam budaya masyarakat kudus yang masih memegang teguh falsafah leluhurnya, sehingga mengantarkan mereka pada sebuahkeberhasilan.Gusjigang sebagai tradisi santri-muslim yang taat, dan tradisi ekonomi perdagangan dan industri, merupakan fenomena yang mampu menjadikan ekonomi masyarakaat Kudus berkembang pesat. Selain itu kearifan lokal juga mampu membangun pendidikan karakter yang mengandung nilai-nilai yang relevan dan berguna bagi pendidikan. Oleh karena itu pendidikan berbasis kearifan lokal dapat dilakukan dengan merevitalisasi budaya lokal. Dengan berlandaskan kearifan lokal maka akan terwujud pendidikan yang mampu memberikan karakter khusus bagi kehidupan manusia. 


\section{BIBLIOGRAPHY}

Adam, Evertt. Jr. and Ronald J. Ebert, Production and Operation's Management $4^{\text {th }} e d$, New Jersey: Prentice Hall, 1989;

Afandi, Agus, "Kekuatan Tradisi Lokal Sebagai Wisdom Yang Membebaskan Masyarakat Dari Belenggu Kekuatan Neoliberalisme", Paper Annual conference on Islamic Studies, Bandung, 28 Desember 2006;.

Ahmad Erani Yustika, Industrialisasi Pinggiran (Yogjakarta: Pustaka Pelajar, 2000), 76.

Aidit b. Haji Ghazali, "A Study of Industrialization From the Qur'a>n, Sunnah and the Islamic Civilization" dalam "Industrialisation From an Islamic Prespective, Kuala Lumpur: IKIM and EPU, 1993;

al-Isfiha>ni>, Abu al-Faraj Kita>b al-Agha>ni>, vol. 1,Beiru>t: Mat\}ba'ah al-'Arabiyyah, tt;

al-Sadr, Kadim "Uang dan kebijakan Moneter pada Periode Awal Islam, dalam Sejarah Pemikiran Ekonomi Islam, Adiwarman Karim, Et.all, Jakarta: The International Institute of Islamic Thought Indonesia [IIIT\}, 2002;

Aoni, Hasan, "Candu Van Kudus", dalam suara Merdeka, 1 September 2004.

Baidhawy, Zakiyuddin, Membumikan Keadilan Meneguhkan Pemihakan Kajian tentang Teori-teori Keadilan Ekonomi Kontemporer dan Prinsip-prinsip Alternatif Tatanan Ekonomi Etis Pro-Mustad afin, Paper annual conference on Islamic studies, Bandung 28 Desember 2006.

Baran, Paul, Political Economy of Growth, New York: Monthly Review-Press, 1957;

Bryant, Coralie dan Louise G White, Manajemen Pembangunan Untuk Negara Berkemban, ter. Rusyanto L Simatupang, Jakarta: LP3ES, 1987;

Cahyono, Edi, „Perburuhan dari masa ke masa: Jaman Kolonial 
Hindia Belanda sampai orde baru" dalam Gerakan serikat Buruh, Jakarta: Hasta Mitra, 2003;

Castle, Lance, Tingkah Laku Agama, Politik dan Ekonomi di Jawa: Industri Rokok Kudus, Yogjakarta: Sinar Harapan, 1982;

Chandra, Rajesh, Industrialization and Development in the Third World, Chapman and Hall, New York, 1992;

Coralie Bryant dan Louise G White, Manajemen Pembangunan Untuk Negara Berkemban, ter. Rusyanto L Simatupang (Jakarta: LP3ES, 1987), 11

Crone, Patricia, Meccan Trade and The Rice Of Islam, New Jersey, Princeton University Press,1987;

Dick,H.W. "Industrialisasi di Abad ke 19", dalam Sejarah Ekonomi Modern Indonesia: Berbagai Tantangan baru, terj. Arief Rahman dan Bambang Purwanto, Jakarta: Pustaka LP3ES, 1998;

Diebold, William, Industrial Policy as an International Issue, New York: Council on Foreign Relations, 1980;

Ensiklopedi Wikipedia Indonesia, “http://id.wikipedia.org/ wiki/Kretek

Esposito, John L, Modern Islamic world, vol. III, New York: Oxford University Press, 1995;

Francis, Abraham, Modernisasi di Dunia Ketiga: Suatu Teori Umum Pembangunan, Yogyakarta: PT. Tiara Wacana, 1991.

Frank,Andre Gunder, The Development of Under development, New York: Monthly Review Press, 1971;

Goulet, Denis The Cruel Choice: A New Concept in the Theory of Development, New York: Atheneum, 1971;

Gramsci, Antonio, "Ekonomi dan Korporasi Negara" dalam Catatan-catan Politik, terj. Gafna Raiza, Surabaya: Pustaka Promethea, 2001; 
Hartono, Anton Wahyu "Menggali Kudus sebagai Kota Kretek", dalam Suara Merdeka, Jumat, 25 Februari 2005.

Hassan, Najib dkk, Jejak Para wali dan Ziarah Spiritual, Jakarta: Kompas, 2006;

Hitti, Philip K. History of The Arabs, London: The Macmillan Press Ltd, 1970;

Iqbal, Munawar \& M. Fahim Khan, A Surveyof Issues and a Programme for Research in Monetary and Fiscal Economics of Islam, Jeddah: ICRIE \&Islamabad: IPS, 1981;

Iskandar, Muhaimin Membajak di Ladang Mesin, Semarang: Yawas, 2004;

Jeffrey E. Garten, "Why the Global Economy is Here to Stay," dalam Business Week, March 23, 1998: 9;

Karim, Adiwarman Azwar Ekonomi Islam: Suatu Kajian Kontemporer, Jakarta: Gema Insani Press, 2002;

Karim, M. Rusli, Berbagai Aspek ekonomi Islam, Yogyakarta: Tiara Wacana, 1992;

Leimgruber, Walter, Between Global and Local, England: Ashgate Publishing Limited, 2004;

Mashuri "Usaha kecil dan Ekonomi Rakyat: Masalah dan Prespektif ke Depan", Jurnal Ekonomi Dan Pembangunan, Vol. VII (2).

-, “Tradisi Ekonomi Santri Masyarakat Kudus dalam Era Otonomi Dan Globalisasi", makalah Seminar "Tradisi Ekonomi Masyarakat Kudus: Antara Otonomi Daerah dan Globalisasi", Kudus tanggal 31 Maret 2001.

, Bakar pecinan, (Jakarta: Pensil-324), 2006)

-, Konflik Sosial di Kudus; Terlibatnya S.I. Kudus Dalam Konflik Sosial Ekonomi, thesis sarjana sejarah Universitas Gadjah Mada, 1981. 
Mas'ud, Abdurrahman, The Pesantren Architects and Their SocioReligious Teachings, (1850 - 1950), Disertasi, UCLA, USA, 1997;

Norman Uphoft dan Warren Ilchman, The Political Economy of Development (Kcrkclcy: University of California Press, 1972), 88.

Pradiptyo, Rimawan, Perkembangan Struktur Kinerja Industri Indonesia dan Libemlisasi Perdagangan Dunia, makalah, UGM, Yogyakarta, 1995;

Pronk, Jan, "Globalization: A Developmental Approach", dalam Jan Nederveen Pieterse (ed.), Global Futures, Shaping Globalization, London: Zed Books, 2001;

Rachbini, Didik J., “Dimensi Ekonomi dan Politik pada Sektor Informal", dalam Prisma, No. 5 Tahun XX, Mei 1991;

Rahman, Fazlur Islam and Modernity Transformation of an Intellectual Tradition, Chicago: The University of Chicago Press,1982;

Rostow,W.W. “Lima Tahap Pertumbuhan Masyarakat: Sebuah Ringhtiuin", dalam Amir Effendi Siregar, Editor, Arus Pemikiran Ekonomi Politik: Esai-Esai Terpilih, Yogyakarta: PT Tiara Wacana, 1991;

Saragih, Bungaran, Agribisnis: Paradigma Baru Pembangunan Ekonomi Berbasis Pertanian, Jakarta: Yayasan Mulia Persada Indonesia-I'usat Studi Pembangunan LPIPB, 1998;

Sarkaniputra, Murassa, " 'adl dan ih\}san dalam ekonomi Islam” dalam Jurnal al-Iqtis\}a>diyyah, vol. 1, januari 2004.

Soepomo, Imam, Hukum Perburuhan Bidang Hubungan Kerja, Jakarta: Djambatan, 1987;

Stevenson,W.J. Production And Operation Management, Illinois: Richard D. Irwin, 1993; 
Suroto, Suri, "Gerakan Buruh dan Permasalahannya“, dalam Prisma no.11 th.1981;

Sutanto, "Prospektif Tenaga Kerja Dalam Hubungan Industrial Sesuai dengan UU Nomor 13 tahun 2003", Makalah disampaikan dalam Kongres Sarjana Ekonomi Indonesia $X V$, Batu, malang, 13-15 Juli 2003;

Todaro, Michael, Economic Development in the Third World, London: Longmans, 1977;

Vinacke, Edghar The Psycholgy of Thinking, Toronto: Mc Graw Hill Book Company Inc, 1992;

Watt,W. Montgomerry Islam dan Peradaban Dunia, terj. Hendro Prasetyo, Jakarta: Gramedia, 1997;

Wee, The Kian, Industrialisasi di Indonesia; Beberapa Kajian, Jakarta: LP3ES, 1994;

Woodward, Mark R., Islam Jawa; Kesalehan Normatif Versus Kebatinan, Lkis, Yogyakarta, 1999;

Zullum, 'Abd al-Qa>dir, al-Amwa $>$ l fidaulah al-khila $>$ fah, Bairu $>\mathrm{t}$ : Da>r al-'Ilm al-Malayyin, 1983; 